\title{
Modification of Daunorubicin-GnRH-III Bioconjugates with Oligoethylene Glycol Derivatives to Improve Solubility and Bioavailability for Targeted Cancer Chemotherapy
}

\begin{tabular}{|r|l|}
\hline Journal: & Biopolymers: Peptide Science \\
\hline Manuscript ID: & BIP-PEP-2015-00003.R1 \\
\hline Watey - Manuscript type: & Original Article \\
\hline Complete List of Authors: & $\begin{array}{l}\text { Hegedüs, Rózsa; MTA-ELTE, Research Group of Peptide Chemistry } \\
\text { Pauschert, Aline; University of Konstanz, Department of Chemistry } \\
\text { Orbán, Erika; MTA-ELTE, Research Group of Peptide Chemistry } \\
\text { Szabó, Ildikó; MTA-ELTE, Research Group of Peptide Chemistry } \\
\text { Andreu, David; Pompeu Fabra University, Experimental and Health } \\
\text { Sciences } \\
\text { Marquardt, Andreas; University of Konstanz, Proteomics Facility } \\
\text { Mező, Gábor; MTA-ELTE, Research Group of Peptide Chemistry } \\
\text { Manea, Marilena; University of Konstanz, Department of Chemistry; }\end{array}$ \\
\hline Keywords: & $\begin{array}{l}\text { drug delivery systems, daunorubicin, gonadotropin-releasing hormone, } \\
\text { oligoethylene glycol, enhanced solubility }\end{array}$ \\
\hline
\end{tabular}




\title{
Modification of Daunorubicin-GnRH-III Bioconjugates with Oligoethylene Glycol Derivatives to Improve Solubility and Bioavailability for Targeted Cancer Chemotherapy
}

\author{
Rózsa Hegedüs ${ }^{1}$, Aline Pauschert ${ }^{2}$, Erika Orbán ${ }^{1}$, Ildikó Szabó ${ }^{1}$, David Andreu ${ }^{3}$, \\ Andreas Marquardt ${ }^{4}$, Gábor Mezö ${ }^{1}$ and Marilena Manea ${ }^{2,5, *}$ \\ ${ }^{1}$ MTA-ELTE Research Group of Peptide Chemistry, 1117 Budapest, Hungary \\ ${ }^{2}$ Department of Chemistry, University of Konstanz, 78457 Konstanz, Germany \\ ${ }^{3}$ Department of Experimental and Health Sciences, Pompeu Fabra University, \\ 08003 Barcelona, Spain \\ ${ }^{4}$ Proteomics Facility, University of Konstanz, 78457 Konstanz, Germany \\ ${ }^{5}$ Zukunftskolleg, University of Konstanz, 78457 Konstanz, Germany
}

\author{
${ }^{*}$ Correspondence to: \\ Dr. Marilena Manea \\ University of Konstanz, Department of Chemistry and Zukunftskolleg, Universitätsstrasse 10, \\ 78457 Konstanz, Germany; Phone: +49 7531882285 \\ E-mail: marilena.manea@,uni-konstanz.de
}




\title{
Modification of Daunorubicin-GnRH-III Bioconjugates with Oligoethylene Glycol Derivatives to Improve Solubility and Bioavailability for Targeted Cancer Chemotherapy
}

\author{
Rózsa Hegedüs ${ }^{1}$, Aline Pauschert ${ }^{2}$, Erika Orbán ${ }^{1}$, Ildikó Szabó ${ }^{1}$, David Andreu ${ }^{3}$, \\ Andreas Marquardt ${ }^{4}$, Gábor Mező ${ }^{1}$ and Marilena Manea ${ }^{2,5,{ }^{*}}$
}

\begin{abstract}
Keywords:
drug delivery systems;

daunorubicin;

gonadotropin-releasing hormone;

oligoethylene glycol;

enhanced solubility;

cytostatic effect.
\end{abstract}




\begin{abstract}
\end{abstract}
Daunorubicin-GnRH-III bioconjugates have recently been developed as drug delivery systems with potential applications in targeted cancer chemotherapy. In order to improve their biochemical properties, several strategies have been pursued: (1) incorporation of an enzymatic cleavable spacer between the anticancer drug and the peptide-based targeting moiety, (2) peptide modification by short chain fatty acids or (3) attachment of two anticancer drugs to the same GnRH-III derivative. Although these modifications led to more potent bioconjugates, a decrease in their solubility was observed. Here we report on the design, synthesis and biochemical characterization of daunorubicin-GnRH-III bioconjugates with increased solubility, which could be achieved by incorporating oligoethylene glycol-based spacers in their structure. First, we have evaluated the effect of an oligoethylene glycol-based spacer on the solubility, enzymatic stability/degradation, cellular uptake and in vitro cytostatic effect of a bioconjugate containing only one daunorubicin attached through a GFLG tetrapeptide spacer to the GnRH-III targeting moiety. Thereafter, more complex compounds containing two copies of daunorubicin, GFLG spacers as well as Lys(nBu) in position 4 of GnRH-III were synthesized and biochemically characterized. Our results indicated that all synthesized oligoethylene glycol-containing bioconjugates had higher solubility in cell culture medium than the unmodified analogs. They were degraded in the presence of rat liver lysosomal homogenate leading to the formation of small drug containing metabolites. In the case of bioconjugates containing two copies of daunorubicin, the incorporation of oligoethylene glycol-based spacers led to increased in vitro cytostatic effect on MCF-7 human breast cancer cells. 


\section{INTRODUCTION}

Tumor targeting with peptides whose receptors are highly expressed on cancer cells is a modern and promising oncological approach, which may significantly decrease the side effects of classical chemotherapy. The application of such peptides as carriers/targeting moieties in a bioconjugate with chemotherapeutic agents can provide a specific receptormediated drug delivery. Furthermore, the slow release of the drug or the intracellular formation of active drug containing metabolites may enhance the therapeutic window of the bioconjugates, in comparison with the administration of free chemotherapeutic agents [1-4].

A promising targeting moiety to be used for the preparation of anticancer drug delivery systems is the hypothalamic decapeptide gonadotropin-releasing hormone (GnRH). In particular, the natural isoform GnRH-III $\left(<\right.$ EHWSHDWKPG- $\mathrm{NH}_{2}$, where $<$ E is pyroglutamic acid) isolated from the sea lamprey (Petromyzon marinus) $[5,6]$ is suitable for this purpose, owing to its binding to the GnRH receptors [7], found to be highly expressed on various types of cancer cells $[3,8]$. Moreover, GnRH-III exerts a direct antiproliferative effect on cancer cells $[9,10]$ and has lower endocrine activity than human GnRH $[3,11-13]$. Furthermore, it has been shown that the modification of lysine in position 8 of GnRH-III did not result in the loss of its biological properties [9]; thus, in our previous studies, the side chain of ${ }^{8}$ Lys was employed as a conjugation site for the formation of symmetric GnRH-III dimers and anticancer drug-peptide bioconjugates $[14,15]$. A panel of anticancer drug-GnRH-III derivative bioconjugates was designed, synthesized and biochemically characterized in our laboratories [16-21]. The most promising compounds contained daunorubicin (Dau) attached via oxime linkage to the $\varepsilon$-amino group of ${ }^{8}$ Lys, either directly or through a GFLG tetrapeptide spacer cleavable by cathepsin B, an enzyme known to be overexpressed in cancer cells. These bioconjugates, GnRH-III $\left[{ }^{8} \mathrm{Lys}(\mathrm{Dau}=\mathrm{Aoa})\right]$ and GnRH-III $\left[{ }^{8} \mathrm{Lys}(\mathrm{Dau}=\mathrm{Aoa}-\right.$ GFLG)] (Aoa = aminooxyacetyl), exerted significant in vitro and in vivo antitumor effect, 
they were stable in human serum for at least $24 \mathrm{~h}$ and degraded in the presence of rat liver lysosomal homogenates $[17,18]$. According to mass spectrometric analysis, no free Dau was released, indicating increased enzymatic and chemical stability of the oxime linkage. The smallest drug containing metabolites produced by lysosomal enzymes that were able to bind in vitro to DNA contained daunorubicin connected to an aminooxyacetylated amino acid [18]. On the basis of these initial results, we further aimed to develop bioconjugates with enhanced enzymatic stability, in particular against digestive enzymes such as chymotrypsin, with increased cellular uptake and antitumor activity. We found that the replacement of ${ }^{4} \mathrm{Ser}$ by $N$ Me-Ser, Lys(Ac) or Lys acylated with short chain fatty acids significantly improved the stability against chymotrypsin and the cellular uptake of oxime bond-linked Dau-GnRH-III derivative bioconjugates $[16,20]$. Regarding their antiproliferative effect, the bioconjugate containing ${ }^{4}$ Lys acylated with butyric acid was the most potent one in breast and colon cancer cells [16]. Moreover, we have shown that on castration resistant prostate cancer cells, the bioconjugate modified in position 4 by Lys(Ac), GnRH-III $\left[{ }^{4} \operatorname{Lys}(\mathrm{Ac}),{ }^{8} \mathrm{Lys}(\mathrm{Dau}=\mathrm{Aoa})\right]$, as well as the parent one, GnRH-III $\left[{ }^{8} \operatorname{Lys}(\mathrm{Dau}=\mathrm{Aoa})\right]$, were rapidly internalized and exerted an antiproliferative effect by inducing apoptosis. This effect was specific, since it was abrogated by simultaneous treatment of the cells with a GnRH antagonist. Furthermore, after GnRHreceptor silencing, the antitumor activity of the bioconjugates was abolished, indicating that the effect of daunorubicin-GnRH-III bioconjugates on cancer cells was mediated by type I GnRH receptor [22].

Another drug design strategy, which led to bioconjugates with enhanced antitumor activity, was the replacement of ${ }^{4}$ Ser by Lys, followed by the attachment of two identical (e.g., Dau) or different chemotherapeutic agents (e.g., Dau and methotrexate) to both ${ }^{4}$ Lys and ${ }^{8}$ Lys of the same targeting moiety. In another version of "multi-drug" containing bioconjugates, two chemotherapeutic agents were attached to both $\alpha$ - and $\varepsilon$-amino groups of 
an additional Lys attached to the side chain of ${ }^{8}$ Lys. Most of these compounds showed higher in vitro cytostatic effect and uptake into cancer cells, as well as increased enzymatic stability than the bioconjugates containing only one anticancer drug $[19,23]$. However, the acylation of lysine in position 4 with fatty acids, the incorporation of a second anticancer drug in a bioconjugate, as well as the presence of a hydrophobic GFLG tetrapeptide spacer led to decreased solubility of the bioconjugates in aqueous buffers and cell culture media.

It has previously been shown that the addition of an ethylene glycol-based spacer may result in cytotoxic bioconjugates with elevated solubility [24-26] or increased stability in circulation, allowing a stable accumulation in the tumor [27]. Thus, the incorporation of an oligoethylene glycol-based spacer may also provide increased solubility to oxime bond-linked Dau-GnRH-III derivative bioconjugates.

On the basis of these previous findings, in the study reported here we aimed to investigate the effect of an oligoethylene glycol-based spacer on the solubility and biochemical properties (i.e., enzymatic stability/degradation, in vitro cytostatic effect) of (1) a bioconjugate in which the anticancer drug daunorubicin was attached via oxime bond, through a GFLG tetrapeptide spacer, to the GnRH-III targeting moiety, and of (2) bioconjugates containing two molecules of daunorubicin attached to a GnRH-III derivative in which ${ }^{4}$ Ser was replaced by Lys(nBu). In the latter bioconjugates, a GFLG spacer was incorporated or not between the anticancer drug and GnRH-based targeting moiety.

Our results indicate that appropriate oligoethylene glycol derivatives may enhance not only the solubility, but also the in vitro cytostatic effect of daunorubicin-GnRH-III derivative bioconjugates, in particular of compounds containing two Dau molecules. Moreover, the incorporation of several structural and functional elements in a bioconjugate is a promising strategy that may result in increased antitumor activity. 


\section{MATERIALS AND METHODS}

\section{Chemicals}

Amino acid derivatives, Fmoc-8-amino-3.6-dioxaoctanoic-acid (Fmoc-EG F $_{2}$ ) and RinkAmide MBHA resin were purchased from Iris Biotech GmbH (Marktredwitz, Germany), while Rink-Amide ChemMatrix resin was from PCAS BioMatrix Inc. (Quebec, Canada). Benzotriazol-1-yloxytrispyrrolidinophosphonium-hexafluoro-phosphate (PyBOP), bis-Bocaminooxyacetic acid (bis-Boc-Aoa-OH), Rink-Amide MBHA resin and Fmoc-12-amino4,7,10-trioxadodecanoic acid $(\text { Fmoc-EG })_{1}$ ) were obtained from NovaBiochem (Läufelfingen, Switzerland). Aminooxyacetic acid, scavengers, coupling agents and cleavage reagents $\left(N, N, N^{\prime}, N^{\prime}\right.$-tetramethyl-O-(1H-benzotriazol-1-yl)uranium-hexafluoro-phosphate (HBTU), 1hydroxybenzotriazole hydrate (HOBt), N,N'-diisopropylcarbodiimide $\quad$ (DIC), triisopropylsilane (TIS), piperidine, 1,8-diazabicyclo[5.4.0]undec-7-ene (DBU), trifluoroacetic acid (TFA)), diisopropylethylamine (DIPEA), acetic anhydride $\left(\mathrm{Ac}_{2} \mathrm{O}\right), 3-(4,5-$ dimethylthiazol-2-yl)-2,5-diphenyltetrazolium bromide (MTT), n-butyric anhydride) were from Sigma-Aldrich Kft (Budapest, Hungary). Ethanol and diethyl ether were Riedel deHäen products (Seelze, Germany). Dimethylformamide (DMF), dichloromethane (DCM) and diethyl ether were purchased from Molar Chemicals Kft (Budapest, Hungary). Acetonitrile $(\mathrm{MeCN})$ for HPLC and 4-methylmorpholine (NMM) were obtained from Sigma-Aldrich Kft. (Budapest, Hungary). Daunorubicin hydrochloride was a gift from IVAX (Budapest, Hungary).

All reagents and solvents were of analytical grade or highest available purity.

Synthesis of oxime bond-linked GnRH-III $\left[^{8} L y s(D a u=A o a-G F L G)\right]$ (1) and GnRHIII ${ }^{8} \operatorname{Lys}($ Dau=Aoa-GFLG-EG $)$ (2) bioconjugates 
The synthesis of GnRH-III $\left[{ }^{8}\right.$ Lys(Dau=Aoa-GFLG) (1) was carried out by a combination of solid phase peptide synthesis and chemical ligation in solution (oxime bond formation) as previously reported [18]. The bioconjugate containing an ethylene glycol-based spacer $\left(\mathrm{EG}_{1}=\right.$ 12-amino-4,7,10-trioxadodecanoic acid), oxime bond-linked GnRH-III $\left[{ }^{8}\right.$ Lys(Dau=AoaGFLG-EG 1 ] (2), was prepared by a slightly different procedure. The aminooxyacetylated derivative of GnRH-III (<EHWSHDWK(Aoa-GFLG-EG $\left.)_{1}\right)$ PG-NH $\mathrm{EH}_{2}$, where $<\mathrm{E}$ is pyroglutamic acid and Aoa is aminooxyacetyl) was prepared manually by solid phase peptide synthesis using Fmoc/tBu chemistry on a Rink-Amide MBHA resin $(0.36 \mathrm{mmol} / \mathrm{g}$ coupling capacity). The following Fmoc-protected amino acid derivatives were used: Fmoc-Gly-OH, Fmoc-Pro-OH, Fmoc-Lys(Mtt)-OH, Fmoc-Trp(Boc)-OH, Fmoc-Asp(OtBu)-OH, FmocHis(Trt)-OH and Fmoc-Ser( $t \mathrm{Bu})-\mathrm{OH}$. The protocol of the synthesis was as follows: (i) DMF washing $(4 \times 1 \mathrm{~min})$, (ii) Fmoc deprotection with $2 \%$ DBU, $2 \%$ piperidine in DMF $(3+7$ min), (iii) DMF washing $(10 \times 1 \mathrm{~min})$, (iv) coupling of 5 equiv Fmoc-protected amino acid:PyBOP:NMM (1:1:2 v/v/v) in DMF (60 min), (v) DMF washing $(4 \times 1 \mathrm{~min})$. After the synthesis of protected linear GnRH-III derivative, the Mtt-protecting group was removed from the $\varepsilon-\mathrm{NH}_{2}$ group of ${ }^{8}$ Lys with $2 \%$ TFA in DCM $(6 \times 5 \mathrm{~min})$, followed by the coupling of

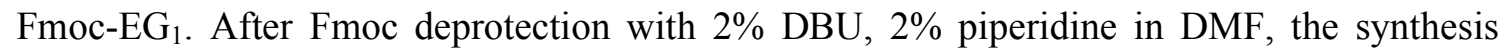
continued with building the GFLG tetrapeptide spacer and coupling of 5 equiv of bis-BocAoa-OH, after preactivation with PyBOP/NMM ( 1 h coupling time). The aminooxyacetylated peptides were cleaved from the resin using a mixture of 95\% TFA, 2.5\% TIS and $2.5 \%$ water $(\mathrm{v} / \mathrm{v} / \mathrm{v})$ in the presence of 10 equiv of free aminooxyacetic acid as a "carbonyl capture" reagent [28], for $2.5 \mathrm{~h}$ at room temperature, precipitated with ice-cold diethyl ether, washed three times with diethyl ether and solubilized in $100 \%$ acetic acid prior to freeze drying. The crude products were purified by semipreparative RP-HPLC and chemically characterized by analytical HPLC and mass spectrometry. 
The conjugation of daunorubicin to the aminooxyacetylated GnRH-III derivatives was carried out in $0.2 \mathrm{M}$ sodium acetate buffer, $\mathrm{pH} 5.0$, at a peptide concentration of $10 \mathrm{mg} / \mathrm{mL}$. Daunorubicin was used in $30 \%$ excess compared to the aminooxyacetylated derivatives of GnRH-III. The reaction mixtures were stirred at room temperature for 24 hours and then subjected to RP-HPLC purification. The purified bioconjugates were characterized by analytical RP-HPLC and mass spectrometry.

Synthesis of GnRH-III[ $\left[^{4} \operatorname{Lys}(n B u),{ }^{8} \operatorname{Lys}(\right.$ Dau=Aoa-X-Y-Lys $($ Dau=Aoa-X-Y))] bioconjugates (where $X=\varnothing, Y=\varnothing(3) ; X=G F L G, Y=\varnothing(4) ; X=\varnothing, Y=E G_{2}(5) ; X=G F L G, Y=E G_{2}(\mathbf{6})$ )

The $\left[{ }^{4}\right.$ Lys]-GnRH-III derivatives acylated with $n$-butyric acid in position 4 and elongated with an additional lysine residue on the side chain of ${ }^{8}$ Lys were prepared by solid phase peptide synthesis according to Fmoc/t Bu chemistry. The branched peptide derivatives were modified on the resin with aminooxyacetic acid attached to both $\alpha$ - and $\varepsilon$-amino groups of the additional Lys, either directly or through (i) an oligoethylene glycol-based spacer $\left(\mathrm{EG}_{2}=8\right.$ amino-3,6-dioxaoctanoic acid), and/or (ii) a GFLG tetrapeptide. The following Fmocprotected amino acid derivatives were used: Fmoc-Gly-OH, Fmoc-Pro-OH, Fmoc-Lys(Mtt)$\mathrm{OH}$, Fmoc-Trp-OH, Fmoc-Asp(OtBu)-OH, Fmoc-His(Trt)-OH, Fmoc-Lys(Dde)-OH and Fmoc-Lys(Fmoc)-OH.

After completing the synthesis of the protected decapeptide, the Dde-protecting group of the $\varepsilon-\mathrm{NH}_{2}$ group of ${ }^{4}$ Lys was removed by $4 \%$ hydrazine in DMF (12 x $\left.5 \mathrm{~min}\right)$; after that, the $n$-butyration of the free $\varepsilon-\mathrm{NH}_{2}$ group was achieved using 3 equiv $n$-butyric anhydride : DIEA $(1: 1, \mathrm{~mol} / \mathrm{mol})$ for $2 \mathrm{~h}$. After removing the Mtt-protecting group from the $\varepsilon-\mathrm{NH}_{2}$ group of ${ }^{8} \mathrm{Lys}$ ( $2 \%$ TFA, $2 \%$ TIS (triisopropylsilane) in DCM for $6 \times 5 \mathrm{~min}$ ), the Fmoc-Lys(Fmoc)-OH was coupled to the resulting free amino group. Then, the Fmoc protecting groups were removed and further modifications were separately performed. In one case, Fmoc-EG 2 was coupled to 
both $\alpha$ - and $\varepsilon$-amino groups of lysine and then the resin was divided into two portions. To one of them, bis-Boc-Aoa-OH was coupled for $2 \mathrm{~h}$ using DIC/HOBt coupling reagents (3 equiv each to the amino groups) (in the case of compound 5 ). In the case of compound $\mathbf{6}$, two copies of the GFLG tetrapeptide spacer were built and then bis-Boc-Aoa-OH was coupled as described before. In the other two cases, the bis-Boc-Aoa-OH was attached directly (for compound 3) to the amino groups of Lys in the branch or to those of the incorporated GFLG spacers (for compound 4), as mentioned above.

The aminooxyacetylated peptides were cleaved from the resin, worked-up, purified and chemically characterized as mentioned above and after that the conjugation of daunorubicin was performed. The reaction mixtures were subjected to RP-HPLC purification and the purified bioconjugates were characterized by analytical RP-HPLC and mass spectrometry.

\section{High performance liquid chromatography (HPLC)}

The bioconjugates $\mathbf{1}$ and $\mathbf{2}$ were purified on a SpectraSystem (Thermo Fisher Scientific, Dreieich, Germany) using a semipreparative Vydac C18 column $(250 \mathrm{~mm}$ x $10 \mathrm{~mm}, 10 \mu \mathrm{m}$ silica, 300 A pore size). Linear gradient elution ( $0 \min 20 \% \mathrm{~B} ; 5 \min 20 \% \mathrm{~B} ; 55 \min 70 \% \mathrm{~B}$ ) with eluent $\mathrm{A}\left(0.1 \%\right.$ TFA in water) and eluent $\mathrm{B}\left(0.1 \%\right.$ TFA in $\left.\mathrm{MeCN}-\mathrm{H}_{2} \mathrm{O}(80: 20, \mathrm{v} / \mathrm{v})\right)$ was used at a flow rate of $4 \mathrm{~mL} / \mathrm{min}$.

Analytical RP-HPLC was performed on an UltiMate 3000 (Dionex, Idstein, Germany) using a Hypersil GOLD C18 column $(250 \mathrm{~mm}$ x $4.6 \mathrm{~mm})$ with $5 \mu \mathrm{m}$ silica (300 ̊ pore size) as a stationary phase (Thermo Fischer, Dreieich, Germany). A linear gradient elution (0 min 0 $\% \mathrm{~B} ; 5 \min 0 \% \mathrm{~B} ; 55 \min 100 \% \mathrm{~B}$ ) was used.

Daunorubicin-GnRH-III derivative bioconjugates 3-6 were purified on a KNAUER 2501 HPLC system (H. Knauer, Bad Homburg, Germany) using a semipreparative Phenomenex Luna C18 column $(250 \mathrm{~mm} \times 10 \mathrm{~mm})$ with $10 \mu \mathrm{m}$ silica (100 $\AA$ pore size) (Torrance, CA). 
Linear gradient elution $(0 \min 20 \% \mathrm{~B} ; 5 \min 20 \% \mathrm{~B} ; 50 \min 100 \% \mathrm{~B})$ with eluent $\mathrm{A}(0.1 \%$ TFA in water $)$ and eluent $\mathrm{B}\left(0.1 \%\right.$ TFA in $\left.\mathrm{MeCN}-\mathrm{H}_{2} \mathrm{O}(80: 20, \mathrm{v} / \mathrm{v})\right)$ was used at a flow rate of $4 \mathrm{~mL} / \mathrm{min}$.

Analytical RP-HPLC of bioconjugates 3-6 was performed on a KNAUER 2501 HPLC system using a Phenomenex Luna C18 column (250 mm x $4.6 \mathrm{~mm})$ with $5 \mu \mathrm{m}$ silica $(100 \AA$ pore size) as a stationary phase. Linear gradient elution $(0 \min 0 \% \mathrm{~B} ; 5 \min 0 \% \mathrm{~B} ; 50 \mathrm{~min}$ $90 \% \mathrm{~B}$ or $0 \min 0 \% \mathrm{~B} ; 2 \min 0 \% \mathrm{~B} ; 25 \mathrm{~min} 100 \% \mathrm{~B}$ ) at a flow rate of $1 \mathrm{~mL} / \mathrm{min}$ with the same eluents described above.

Mass spectrometry (MS)

Electrospray (ESI)-mass spectrometric analyses were carried out on an Esquire 3000+ ion trap mass spectrometer (Bruker Daltonics, Bremen, Germany). Spectra were acquired in the $50-2500 \mathrm{~m} / \mathrm{z}$ range. Samples were dissolved in a mixture of $50 \%$ methanol, $48 \%$ water and $2 \%$ acetic acid.

Liquid chromatography-mass spectrometry (LC-MS) was carried out on an Esquire 3000+ ion trap mass spectrometer (Bruker Daltonics, Bremen, Germany) equipped with an Agilent 1100 HPLC system (Agilent, Waldbronn, Germany) and a diode array detector. Peptides were separated on a Vydac MS C18 column (150 mm x 1 mm; $300 \AA, 3 \mu \mathrm{m})$ using a linear gradient from $90 \%$ eluent A $(0.1 \%$ formic acid in water $(\mathrm{v} / \mathrm{v}))$ and $10 \%$ eluent $\mathrm{B}(0.1 \%$ formic acid in acetonitrile (v/v)) to $70 \%$ eluent B over 60 minutes and a flow rate of $50 \mu \mathrm{L} / \mathrm{min}$. Spectra were recorded in positive ion mode in the $50-2500 \mathrm{~m} / \mathrm{z}$ range.

\section{Solubility determination of the bioconjugates using an HPLC-based approach}

The solubility of the bioconjugates in DMEM cell culture medium was determined as follows: a $2 \mathrm{mM}$ aqueous solution of each bioconjugate was diluted with cell culture medium 
to obtain a $100 \mu \mathrm{M}$ concentration. This solution was incubated for $15 \mathrm{~min}$ at room temperature and then centrifuged for $15 \mathrm{~min}$ at $13000 \mathrm{rpm}$. From the obtained supernatant, an appropriate volume, which should contain $30 \mu \mathrm{g}$ of bioconjugate - assuming that it would have been completely soluble at a concentration of $100 \mu \mathrm{M}$ - was taken and diluted to a volume of $500 \mu \mathrm{L}$ with $0.1 \%$ TFA in water (HPLC eluent A). A reason for diluting the solution with eluent $\mathrm{A}$ was also to adjust the $\mathrm{pH}$ to 2.5 , before analyzing the sample by analytical RP-HPLC. In the case of bioconjugates $\mathbf{1}$ and $\mathbf{2}$, the analyses were performed on an UltiMate 3000 HPLC system (Dionex, Idstein, Germany) as described above. The bioconjugates containing two copies of daunorubicin were analyzed on an Exformma EX1600 HPLC system (Wincom, Shanghai, China) using a Zorbax SB-C18 column (150 x $4.6 \mathrm{~mm}, 5$ $\mu \mathrm{m}$ silica, pore size $80 \AA$ ) and the following linear gradient: $0 \min 0 \% \mathrm{~B} ; 2 \min 0 \% \mathrm{~B} ; 22$ min $90 \%$ B (eluent A: $0.1 \%$ TFA in water; eluent B: 0.1\% TFA in acetonitrile:water (80:20, $\mathrm{v} / \mathrm{v})$ ). HPLC profiles of the eluents and of cell culture medium were also recorded, in order to assign and subtract all signals that were not given by the bioconjugates. Based on standard curves obtained with different amounts of bioconjugates dissolved in water, the solubility of each bioconjugate in cell culture medium was assessed by extrapolation.

\section{Stability of $G n R H-I I I\left[{ }^{8} \operatorname{Lys}\left(D a u=A o a-G F L G-E G_{1}\right)\right]$ bioconjugate in human serum}

The stability of GnRH-III $\left[\left({ }^{8} \operatorname{Lys}\left(\mathrm{Dau}=\mathrm{Aoa}-\mathrm{GFLG}-\mathrm{EG}_{1}\right)\right]\right.$ in $90 \%$ human serum was determined as previously reported for GnRH-III[ $\left({ }^{8} \mathrm{Lys}(\mathrm{Dau}=\mathrm{Aoa}-\mathrm{GFLG})\right]$ [18]. Briefly, the bioconjugate was first dissolved in water to obtain a stock solution of $100 \mu \mathrm{M}$ concentration, which was added to human serum, so that the final bioconjugate concentration was $10 \mu \mathrm{M}$. The mixture was incubated at $37^{\circ} \mathrm{C}$ and aliquots were taken after $5 \mathrm{~min}$ and $24 \mathrm{~h}$. After quenching the reactions with acetic acid, the large human serum proteins were removed using Microcon centrifugal filter devices with 10 kDa cut-off (Millipore Corporation, Bedford, MA, 
USA), followed by the LC-MS analysis of the lower molecular weight fraction. Two control experiments were also performed: (1) 90\% human serum and (2) an aqueous solution of the bioconjugate $(\mathrm{c}=10 \mu \mathrm{M})$ were incubated at $37^{\circ} \mathrm{C}$ and aliquots taken after $5 \mathrm{~min}$ and $24 \mathrm{~h}$ were analyzed by LC-MS.

Degradation of oxime bond-linked Daunorubicin-GnRH-III derivative bioconjugates in the presence of rat liver lysosomal homogenate

The rat liver lysosomal homogenate was prepared as previously described [16,18-21]. The protein concentration was determined by Pierce BCA (bicinchoninic acid) protein assay, according to the manufacturer's protocol (ThermoFisher Scientific, Rockford, IL,) and it was $17.4 \mu \mathrm{g} / \mu \mathrm{L}$. The bioconjugates were dissolved in $0.2 \mathrm{M} \mathrm{NaOAc}, \mathrm{pH} 5.0$, at a concentration of $0.1 \mu \mathrm{g} / \mu \mathrm{L}$ and then the rat liver lysosomal homogenate was added (bioconjugate : lysosomal homogenate ratio $=1: 1, \mathrm{w} / \mathrm{w}$ ). The reaction mixtures were incubated at $37^{\circ} \mathrm{C}$ and aliquots of $50 \mu \mathrm{L}$ were taken after $5 \mathrm{~min}, 1 \mathrm{~h}, 2 \mathrm{~h}, 4 \mathrm{~h}, 6 \mathrm{~h}, 8 \mathrm{~h}$ and $24 \mathrm{~h}$. The reactions were quenched by adding $5 \mu \mathrm{L}$ of acetic acid, followed by freezing the samples and storage at $-28^{\circ} \mathrm{C}$ until further analysis. Each aliquot was then subjected to LC-MS analysis. Control experiments were performed by incubating the bioconjugate solutions $(0.1 \mu \mathrm{g} / \mu \mathrm{L}$ in $0.2 \mathrm{M}$ sodium acetate buffer, $\mathrm{pH} 5.0$ ) at $37^{\circ} \mathrm{C}$ for $24 \mathrm{~h}$, followed by LC-MS analysis, in order to assess their chemical stability under these experimental conditions.

Cells

MCF-7 (ATCC:HTB-22) human breast adenocarcinoma cells were maintained in DMEM (Sigma Ltd., St. Louis, MO) medium containing 10\% FCS (fetal calf serum, Sigma Ltd.), Lglutamine $(2 \mathrm{mM})$, gentamicin $(160 \mu \mathrm{g} / \mathrm{mL}), 1 \mathrm{mM}$ pyruvate and non-essential amino acids 
(Sigma Ltd.). The cell culture was maintained at $37^{\circ} \mathrm{C}$ in a humidified atmosphere with $5 \%$ $\mathrm{CO}_{2}$.

\section{Cellular uptake of bioconjugates 1 and $\mathbf{2}$ determined by flow cytometry}

To determine the cellular uptake of bioconjugates 1 and 2, MCF-7 human breast cancer cells were plated at a number of $1 \times 10^{5}$ cells per well on 24-well plates in $1 \mathrm{~mL}$ complete medium. After $24 \mathrm{~h}$ incubation at $37^{\circ} \mathrm{C}$, cells were centrifuged for $5 \mathrm{~min}$ at $1000 \mathrm{rpm}$ and the supernatant was removed. Thereafter, $250 \mu \mathrm{L}$ of bioconjugate solutions (in serum-free medium) were added onto the cells in the $0.16 \mu \mathrm{M}$ to $100 \mu \mathrm{M}$ concentration range. Control cells were treated with serum-free medium. Cells were incubated with bioconjugate solutions at $37^{\circ} \mathrm{C}$ for $6 \mathrm{~h}$. After that, the solutions were removed from the cells, $100 \mu \mathrm{L}$ trypsin were added per well and incubated for $10 \mathrm{~min}$ at $37^{\circ} \mathrm{C}$. After adding $900 \mu \mathrm{L}$ of HPMI (glucose, $\mathrm{NaHCO}_{3}, \mathrm{NaCl}$, HEPES, $\mathrm{KCl}, \mathrm{MgCl}_{2}, \mathrm{CaCl}_{2}, \mathrm{Na}_{2} \mathrm{HPO}_{4} \cdot 2 \mathrm{H}_{2} \mathrm{O}$ ) supplemented with $10 \% \mathrm{FCS}$, cells were transferred to FACS tubes and centrifuged for $5 \mathrm{~min}$ at $1000 \mathrm{rpm}$. After that, the supernatant was removed and the cells were resuspended in $500 \mu \mathrm{L}$ HPMI. Fluorescence intensity of the cells was determined by flow cytometry (BD LSR II, BD Bioscience, San Jose, CA, USA). Data were analyzed with the FACSDiVa software.

\section{In vitro cytostatic effect of the bioconjugates determined by MTT assay}

The in vitro cytostatic effect of the bioconjugates was determined by 3-(4,5dimethylthiazol-2-yl)-2,5-diphenyltetrazolium bromide assay (MTT assay). One day before the treatment, $5 \times 10^{3} \mathrm{MCF}-7$ cells per well were plated on 96-well plates. After $24 \mathrm{~h}$ incubation at $37^{\circ} \mathrm{C}$, the cells were treated for $6 \mathrm{~h}$ with the bioconjugates used in the $0.256-100$ $\mu \mathrm{M}$ concentration range. The solutions were prepared in serum-free medium. Cells treated for $6 \mathrm{~h}$ with serum-free medium were used as a control. After treatment and incubation, cells were 
washed twice with serum-free medium and cultured in serum containing medium for $72 \mathrm{~h}$. On the fourth day, the MTT assay was performed. MTT was added to each well (final concentration: $367 \mu \mathrm{g} / \mathrm{mL}$ ) and during $3.5 \mathrm{~h}$ incubation at $37^{\circ} \mathrm{C}$, purple crystals were formed by mitochondrial dehydrogenase enzyme present in the living cells. After that, cells were centrifuged for $5 \mathrm{~min}$ at $2000 \mathrm{rpm}$ and the supernatant was removed. The crystals were dissolved in $100 \mu \mathrm{L}$ DMSO and the optical density (OD) was determined at $\lambda=540$ and 620 nm using an ELISA Reader (Labsystems MS reader, Helsinki, Finland). OD $_{620}$ was subtracted from $\mathrm{OD}_{540}$ and the percentage of cytostasis was calculated using the following equation:

Cytostasis $\%=\left[1-\left(\mathrm{OD}_{\text {treated }} / \mathrm{OD}_{\text {control }}\right)\right] \times 100$

where $\mathrm{OD}_{\text {treated }}$ and $\mathrm{OD}_{\text {control }}$ correspond to the optical densities of treated and control cells, respectively. Cytostasis \% was plotted as a function of concentration, fitted to a sigmoid curve and the $50 \%$ inhibitory concentration $\left(\mathrm{IC}_{50}\right)$ value was determined from these curves.

\section{RESULTS AND DISCUSSION}

Oligoethylene glycol-modified bioconjugate containing only one daunorubicin attached through a GFLG tetrapeptide spacer to the GnRH-III targeting moiety

Synthesis and chemical characterization of GnRH-III based bioconjugates containing only one daunorubicin

The syntheses of bioconjugates 1 (GnRH-III $\left[{ }^{8} \mathrm{Lys}(\mathrm{Dau}=\mathrm{Aoa}-\mathrm{GFLG})\right]$ and $\mathbf{2}$ (GnRH$\mathrm{III}\left[{ }^{8} \mathrm{Lys}\left(\mathrm{Dau}=\mathrm{Aoa}-\mathrm{GFLG}_{-} \mathrm{EG}_{1}\right)\right] ; \mathrm{EG}_{1}$ is $4,7,10$-trioxadodecanoic acid) containing only one Dau (Figure 1) were carried out by a combination of solid phase peptide synthesis (Fmoc/t $\mathrm{Bu}$ chemistry) and chemical ligation in solution (oxime bond formation), as previously published [18]. Both bioconjugates were purified by semipreparative RP-HPLC and then the purified compounds were characterized by analytical RP-HPLC and mass spectrometry (bioconjugate 1: $\mathrm{R}_{\mathrm{t}}=31.5 \mathrm{~min} ; \mathrm{MW}_{\text {calc }} / \mathrm{MW}_{\mathrm{exp}}=2216.3 / 2215.9$; bioconjugate $2: \mathrm{R}_{\mathrm{t}}=31.7 \mathrm{~min} ; \mathrm{MW}_{\text {calc }} /$ 
$\mathrm{MW}_{\exp }=2419.6 / 2419.1$; Figures S1 and S2 in Supporting Information). As previously reported, fragmentation of the glycosidic bonds during electrospray-mass spectrometric (ESIMS) analysis could be observed, resulting in the loss of daunosamine moiety $(-129,-147)[16$, 18]. These fragments were labeled in all mass spectra with an asterisk.

Solubility of bioconjugates 1 and 2 in cell culture medium determined by an HPLC-based approach

Solubility determinations are generally based on weight measurements [29], which are not precise in the case of low amounts of sample. To evaluate the influence of the oligoethylene glycol-based spacer on the solubility of oxime bond-linked Dau-GnRH-III derivative bioconjugates in cell culture medium, an RP-HPLC based approach was established in the present study. This method was based on AUC determinations and it only required a standard curve, which was first recorded using different concentrations of a particular bioconjugate dissolved in water. Thereafter, a sample which should contain a certain amount of bioconjugate ( $30 \mu \mathrm{g}$, assuming that it would completely be soluble) was analyzed (Figure S3 in Supporting Information).

Our results indicated that the incorporation of an oligoethylene glycol-based spacer led to a bioconjugate 2 with significantly higher solubility than $1(78.8 \% v s .42 .5 \%$, Table 1$)$ in cell culture medium.

Enzymatic stability/degradation of bioconjugates 1 and 2 in human serum and lysosomal homogenate

An important feature of targeted cancer chemotherapeutics is their stability in human serum until they reach the site of action, since premature drug release would lead to undesirable side effects. On the other hand, bioconjugates need to be processed in the cells, 
particularly in lysosomes, in order to release the free drug or to generate drug-containing metabolites displaying antitumor activity.

Degradation of bioconjugate $\mathbf{1}$ in the presence of rat liver lysosomal homogenate has previously been reported [18] and results are summarized in Figure 1A and Table S1. The degradation of bioconjugate 2 was investigated by LC-MS, which led to the identification of several cleavage sites, both within the GFLG spacer and the GnRH-III sequence (Figure 1B and Table S1).

In agreement with our previous findings, no free daunorubicin was detected by LC-MS, indicating substantial chemical and enzymatic stability of the oxime bond $[16,18]$. The smallest drug containing metabolite generated in the case of both bioconjugates in the presence of lysosomal enzymes and identified by mass spectrometry was Dau=Aoa-Gly-OH $(\mathrm{m} / z 658.1(1+))$ (Figure S4 in Supporting Information). We have previously shown that this drug containing metabolite was able to bind to DNA in vitro, thus providing an explanation for the antitumor activity of the bioconjugates. Taken together, these results allow concluding that the oligoethylene glycol-based spacer did not influence the enzymatic degradation of the bioconjugate, in particular when an enzymatic cleavable GFLG tetrapeptide spacer was incorporated in its structure.

Furthermore, the effect of the oligoethylene glycol spacer on the stability of bioconjugate $\mathbf{2}$ in human serum was also investigated. We have previously reported that various oxime bond-linked Dau-GnRH-III derivative bioconjugates developed in our laboratories, including compound 1, were stable in human serum for at least $24 \mathrm{~h}[18,20]$. In the present study, the influence of the oligoethylene glycol-based spacer on the stability of bioconjugate 2 in human serum was determined by LC-MS. After $5 \mathrm{~min}$ and $24 \mathrm{~h}$ incubation at $37^{\circ} \mathrm{C}$, aliquots were taken from the reaction mixture and subjected to MS analysis, which indicated that the incorporation of an oligoethylene glycol-based spacer in the structure of the bioconjugate did 
not influence its stability in human serum, in comparison with that of compound 1; intact bioconjugate 2 was detectable by mass spectrometry even after $24 \mathrm{~h}$ incubation with human serum (Figure 2A). As described in the experimental section, two control experiments were performed, in which both $90 \%$ human serum and an aqueous solution of the bioconjugate were incubated at $37^{\circ} \mathrm{C}$ and analyzed by LC-MS, in order to facilitate the interpretation of mass spectrometric data and to also assess the chemical stability of the bioconjugate (Figures $2 \mathrm{~B}$ and $2 \mathrm{C})$.

\section{Cellular uptake of bioconjugates 1 and $\mathbf{2}$ determined by flow cytometry}

Based on the fluorescence properties of daunorubicin [18], the uptake of bioconjugates 1 and 2 by MCF-7 human breast cancer cells was determined by flow cytometry, at different bioconjugate concentrations (between 0.16 and $100 \mu \mathrm{M}$ ). As shown in Figure 3, both compounds were taken up by MCF-7 cells in a concentration dependent manner; however, no significant differences could be observed in the entire concentration range. Very slight differences could be determined at a concentration of $4 \mu \mathrm{M}$, the oligoethylene glycol containing compound being characterized by an elevated cellular uptake (Dau positive MCF-7 cells: $8.6 \%$ vs. $6.0 \%)$.

\section{Cytostatic effect of bioconjugates 1 and 2}

The in vitro cytostatic effect of bioconjugates $\mathbf{1}$ and $\mathbf{2}$ was evaluated on MCF-7 human breast cancer cells by 3-(4,5-dimethylthiazol-2-yl)-2,5-diphenyltetrazolium bromide (MTT) assay. The $\mathrm{IC}_{50}$ values were determined on the basis of the dose-response curves (Figure S5 in Supporting Information) and indicated no significant difference between the in vitro cytostatic effect of both bioconjugates $\left(\mathrm{IC}_{50}=3.6 \pm 0.5 \mu \mathrm{M}\right.$ for bioconjugate 1 and $5.1 \pm 0.5$ for bioconjugate 2, respectively). Compared to free daunorubicin $\left(\mathrm{IC}_{50}=0.4 \pm 0.1 \mu \mathrm{M}\right)[21]$, both 
bioconjugates exerted lower in vitro cytostatic effect. This result is in agreement with our previous studies and can be explained by the mechanisms of cellular uptake, namely passive diffusion in the case of free Dau vs. receptor-mediated endocytosis, which is followed by intracellular processing of the bioconjugates. In the particular case of oxime bond-linked DauGnRH-III bioconjugates $\mathbf{1}$ and 2, no free Dau release was observed in the presence of lysosomal homogenates; Dau=Aoa-Gly-OH was the smallest drug containing metabolite identified by LC-MS. This might provide an additional explanation for the different in vitro cytostatic effect of free and conjugated Dau. The advantage of oxime bond-linked DauGnRH-III bioconjugates over the application of free Dau can be seen in vivo. In a recent study, we have shown that bioconjugate 1 exerted significant tumor growth inhibitory effect on colon carcinoma bearing mice, while no signs of toxicity were detected on healthy mice $[17,30]$. Moreover, compared to free Dau, the bioconjugate had broader therapeutic window. Taken together, these results support the concept of targeted cancer chemotherapy, namely increased selectivity and decreased peripheral toxicity of conjugated anticancer drugs.

\section{Oligoethylene glycol modified GnRH-III based bioconjugates containing two copies of daunorubicin}

Synthesis and chemical characterization of GnRH-III based bioconjugates containing two copies of daunorubicin

We have previously shown that the attachment of two Dau molecules to the same GnRHIII based targeting moiety resulted in bioconjugates that exerted higher in vitro cytostatic effect than the parent bioconjugate GnRH-III $\left[{ }^{8} \operatorname{Lys}(\mathrm{Dau}=\mathrm{Aoa})\right]$, in which Dau was attached via oxime bond to the native GnRH-III. We have also found that the replacement of ${ }^{4}$ Ser by Lys $(\mathrm{nBu})$ in the GnRH-III sequence led to a bioconjugate with increased antitumor activity than GnRH-III $\left[{ }^{8} \mathrm{Lys}(\mathrm{Dau}=\mathrm{Aoa})\right]$. On the basis of these results, in the study reported here we 
aimed to combine the structural elements mentioned above in a single bioconjugate; i.e., the attachment of two Dau units to a GnRH-III derivative modified in position 4 by Lys(nBu). In another bioconjugate, a GFLG tetrapeptide spacer was also incorporated between Dau and the targeting moiety, with the aim of facilitating intracellular drug release. Since these modifications may lead to decreased solubility of the biocojugates, two compounds containing oligoethylene glycol-based spacers were also synthesized and characterized, with special emphasis on the influence of the oligoethylene glycol on their solubility, enzymatic degradation and antitumor activity. In this case, a slightly different oligoethylene glycol derivative was used; namely, 8-amino-3,6-dioxaoctanoic acid, which may provide increased solubility and is more affordable than 12-amino-4,7,10-trioxadodecanoic acid. For the synthesis of bioconjugates 3-6, the lysine residues in positions 4 and 8 were orthogonally protected (position 4: Lys(Dde), position 8: Lys(Mtt)) in order to selectively perform their deprotection and further modifications (Scheme 1). The cleavage of the Dde protecting group and the acylation of ${ }^{4}$ Lys with butyric acid were carried out prior to the removal of Mtt under acidic conditions, followed by the attachment of a further lysine derivative (Fmoc-Lys(Fmoc)$\mathrm{OH})$, which provided two attachment sites. After removing the Fmoc groups, both $\alpha$ - and $\varepsilon-$ amino groups of Lys in the branch were modified by aminooxyacetylation, thus allowing the attachment of two Dau copies via oxime bond (in order to prepare bioconjugate 3). For the preparation of compounds 4-6, the $\alpha$ - and $\varepsilon$-amino groups of Lys in the branch were used for building the GFLG spacers or for the attachment of oligoethylene glycol derivatives, followed by aminooxyacetylation. All compounds were cleaved from the resin with a mixture of TFA and appropriate scavengers. Daunorubicin was conjugated to the aminooxyacetylated GnRHIII derivatives by oxime ligation, which was carried out under slightly acidic conditions ( $\mathrm{pH}$ 5.0). After purification by semipreparative RP-HPLC, bioconjugates 3-6 were characterized by analytical RP-HPLC and MS (bioconjugate 3: $\mathrm{R}_{\mathrm{t}}=28.5 \mathrm{~min} ; \mathrm{MW}_{\text {calc }} / \mathrm{MW}_{\exp }=2661.8 /$ 
2662.8; bioconjugate 4: $\mathrm{R}_{\mathrm{t}}=33.1 \mathrm{~min} ; \mathrm{MW}_{\text {calc }} / \mathrm{MW}_{\exp }=3410.8 / 3411.3$; bioconjugate 5: $\mathrm{R}_{\mathrm{t}}$ $=27.0 \mathrm{~min} ; \mathrm{MW}_{\text {calc }} / \mathrm{MW}_{\text {exp }}=2952.2 / 2953.0 ;$ bioconjugate 6: $\mathrm{R}_{\mathrm{t}}=30.7 \mathrm{~min} ; \mathrm{MW}_{\text {calc }} /$ $\mathrm{MW}_{\exp }=3701.0$ / 3701.4; Figures S6 - S9 in Supporting Information). Their structures are represented in Figure 4.

\section{Solubility determination of bioconjugates 3-6 using an HPLC-based approach}

The solubility of bioconjugates 3-6 containing two Dau copies was determined by the HPLC-based approach described above. As summarized in Table 2, incorporation of the oligoethylene glycol based spacer significantly improved the solubility of the compounds, from $16.4 \%$ (bioconjugate 3 ) to $45.1 \%$ (bioconjugate 5 ) and from $1.6 \%$ (bioconjugate 4 ) to $10.6 \%$ (bioconjugate 6 ), respectively.

Enzymatic degradation of bioconjugates 3-6 in the presence of lysosomal enzymes

The degradation of butyrated bioconjugates 3-6 in the presence of lysosomal enzymes was determined by LC-MS, as described above. Cleavage sites were identified within the GFLG spacer (bioconjugates 4 and 6) and GnRH-III sequence (bioconjugates 3-6), as well. Furthermore, the isopeptide bond between ${ }^{8}$ Lys and the additional Lys in the braches was cleaved in bioconjugates 3-5. In agreement with our previous findings reported for compound GnRH-III $\left[{ }^{4} \operatorname{Lys}(\mathrm{nBu}),{ }^{8} \mathrm{Lys}(\mathrm{Dau}=\mathrm{Aoa})\right]$ [16], the fragment detected at $m / z 581.3(1+)$ was assigned to peptide $<$ EHWK-OH, indicating cleavage of the amide bond between the ${ }^{4}$ Lys and the fatty acid (Figure 4). The release of free butyric acid in cancer cells may play an important role in inducing an apoptotic effect [31-33]. The formation of the smallest drug containing fragment was strongly dependent on the structure of the bioconjugates. The recorded mass spectra of bioconjugates 3-6 incubated with the lysosomal homogenate are shown in the Supporting Information, Figures S10-S13 and the identified fragments are 
summarized in Table S2. The smallest Dau containing metabolites identified by MS were as follows: bioconjugate 3: $[\mathrm{Dau}=\mathrm{Aoa}-\mathrm{Lys}(\mathrm{Dau}=\mathrm{Aoa})]-\mathrm{OH}$ detected at $\mathrm{m} / z \quad 655.8(2+)$, bioconjugate 4: Dau=Aoa-Gly-OH detected at $m / z 658.1(1+))$, bioconjugate 5: Dau=Aoa$\mathrm{EG}_{2}-\mathrm{OH}$ detected at $\mathrm{m} / z 745.1(1+)$, bioconjugate 6: Dau=Aoa-Gly-OH detected at $\mathrm{m} / z 658.1$ $(1+))$.

We have previously shown that both H-Lys(Dau=Aoa)-OH and Dau=Aoa-Gly-OH could efficiently bind DNA in vitro, this result providing an explanation for the cytostatic effect and mechanism of action of the bioconjugate [18]. From the bioconjugate $\mathbf{3}$, in which Dau=Aoa was directly attached to both amino groups of the additional Lys coupled to ${ }^{8}$ Lys of GnRH-III, a fairly large fragment was identified as being the smallest drug containing metabolite produced by lysosomal enzymes. This finding may explain its lower cytostatic effect (Table 3). In bioconjugate $\mathbf{5}, \mathrm{Dau}=\mathrm{Aoa}$ is connected to the ethylene glycol moiety and Dau=Aoa$\mathrm{EG}_{2}-\mathrm{OH}$ was detected by mass spectrometry as the smallest drug containing metabolite.

\section{In vitro cytostatic effect of bioconjugates 3-6}

The in vitro cytostatic effect of bioconjugates 3-6 was determined on MCF-7 human breast cancer cells by MTT assay (Table 3). The incorporation of the GFLG tetrapeptide spacer and/or oligoethylene glycol moiety led to an increased antiproliferative effect of bioconjugates 4-6 $\left(\mathrm{IC}_{50}=1.3 \pm 0.4 \mu \mathrm{M}, 0.9 \pm 0.4 \mu \mathrm{M}\right.$ and $0.5 \pm 0.1 \mu \mathrm{M}$, respectively) compared to compound $3\left(\mathrm{IC}_{50}=7.7 \pm 0.4 \mu \mathrm{M}\right)$. The latter analog was also the least sensitive to degradation in the presence of lysosomal homogenate, resulting in the largest Dau containing metabolite. To elucidate whether the increased cytostatic effect is derived from the elevated solubility of the oligoethylene glycol containing bioconjugates or/and from the type of released metabolites, further studies are necessary.

Taken together, the results reported here indicate that bioconjugates $\mathbf{5}$ and $\mathbf{6}$, which contain two copies of Dau and of an oligoethylene glycol moiety, had the highest in vitro 
cytostatic effect on MCF-7 human breast cancer cells. By comparing bioconjugates $\mathbf{3}$ and $\mathbf{4}$, we found that the incorporation of a GFLG spacer led to elevated antitumor activity, a result that may be explained by the size of the drug containing metabolites produced in the presence of lysosomal enzymes. On the basis of these results, it can be concluded that incorporation of several structural and functional elements in a bioconjugate may provide improved physicochemical and biological properties.

\section{CONCLUSIONS}

In the present work, GnRH-III and its derivative modified in position 4 by Lys(nBu) were employed as targeting moieties to which one or two copies of Dau were attached via oxime bond, leading to the formation of drug delivery systems with potential applications in targeted cancer chemotherapy. In order to facilitate the drug release, a cathepsin B-cleavable GFLG tetrapeptide spacer was also incorporated in some of the bioconjugates. Furthermore, oligoethylene glycol-based spacers were used with the primary goal of improving their solubility and biological properties (e.g., the antiproliferative activity).

In the case of a bioconjugate containing only one Dau attached through a GFLG spacer to the native GnRH-III, the incorporation of an oligoethylene glycol spacer led to enhanced solubility in cell culture medium, as determined by an HPLC-based approach. However, no significant influence of the oligoethylene glycol moiety on the in vitro stability/degradation, cellular uptake and cytostatic effect of the bioconjugate was observed.

The incorporation of oligoethylene glycol spacers in the structure of bioconjugates containing two Dau copies attached to GnRH-III[ $\left[{ }^{4} \mathrm{Lys}(\mathrm{nBu})\right]$ led to elevated solubility as well. The degradation of these "multi-drug" bioconjugates in the presence of rat liver lysosomal homogenate was investigated by LC-MS, which indicated that the formation of the smallest drug containing fragments was strongly dependent on bioconjugate structure. Furthermore, 
the compounds containing the oligoethylene glycol moiety showed enhanced cytostatic effect on MCF-7 human breast cell lines.

Taken together, these results suggest that appropriate oligoethylene glycol derivatives may enhance not only the solubility, but also the in vitro cytostatic effect of Dau-GnRH-III derivative bioconjugates developed as drug delivery systems. In a long term perspective, the incorporation of several structural and functional elements in a bioconjugate is a promising strategy that may result in increased antitumor activity of anticancer drug-peptide bioconjugates, with potential applications in targeted cancer chemotherapy.

\section{Supporting Information}

Additional Supporting Information may be found in the online version of this article.

\section{Acknowledgements}

This work was supported by grants from the Hungarian National Science Fund (OTKA 104045), TéT ES-20/2008 and University of Konstanz (Zukunftskolleg, Project 634/12). 


\section{REFERENCES}

1. Singh, Y.; Palombo, M.; Sinko, P. J. Curr Med Chem 2008, 15, 1802-1826.

2. Schally, A. V.; Nagy, A. Eur J Endocrinol 1999, 141, 1-14.

3. Mező, G.; Manea, M. Expert Opin Drug Deliv 2010, 7, 79-96.

4. Nukolova, N. V.; Oberoi, H. S.; Zhao, Y.; Chekhonin, V. P.; Kabanov, A. V.; Bronich, T. K. Mol Pharm 2013, 10, 3913-3921.

5. Sower, S. A.; Chiang, Y. C.; Lovas, S.; Conlon, J. M. Endocrinology 1993, 132, $1125-$ 1131.

6. Manea, M.; Mező, G. Protein Pept Lett 2013, 20, 439-449.

7. Millar, R. P. Anim Reprod Sci 2005, 88, 5-28.

8. Nagy, A.; Schally, A. V. Biol Reprod 2005, 73, 851-859.

9. Mező, I.; Lovas, S.; Pályi, I.; Vincze, B.; Kálnay, A.; Turi, G.; Vadász, Z.; Seprődi, J.; Idei, M.; Tóth, G.; Gulyás, E.; Ötvös, F.; Mák, M.; Horváth, J. E.; Teplán, I.; Murphy, R. F. J Med Chem 1997, 40, 3353-3358.

10. Mező, G.; Manea, M.; Szabó, I.; Vincze, B.; Kovács, M. Curr Med Chem 2008, 15, 23662379.

11. Lovas, S.; Pályi, I.; Vincze, B.; Horváth, J.; Kovács, M.; Mező, I.; Tóth, G.; Teplán, I.; Murphy, R. F. J Pept Res 1998, 52, 384-389.

12. Kovács, M.; Seprődi, J.; Koppán, M.; Horváth, J. E.; Vincze, B.; Teplán, I.; Flerkó, B. J Neuroendocrinol 2002, 14, 647-655.

13. Kovács, M.; Vincze, B.; Horváth, J. E.; Seprődi, J. Peptides 2007, 28, 821-829.

14. Schreier, V. N.; Mező, G.; Orbán, E.; Dürr, C.; Marquardt, A.; Manea, M. Bioorg Med Chem Lett 2013, 23, 2145-2150.

15. Mező, G.; Czajlik, A.; Manea, M.; Jakab, A.; Farkas, V.; Majer, Z.; Vass, E.; Bodor, A.; Kapuvári, B.; Boldizsár, M.; Vincze, B.; Csuka, O.; Kovács, M.; Przybylski, M.; Perczel, A.; Hudecz, F. Peptides 2007, 28, 806-820.

16. Hegedüs, R.; Manea, M.; Orbán, E.; Szabó, I.; Kiss, E.; Sipos, E.; Halmos, G.; Mező, G. Eur J Med Chem 2012, 56, 155-165.

17. Szabó, I.; Manea, M.; Orbán, E.; Csámpai, A.; Bősze, S.; Szabó, R.; Tejeda, M.; Gaál, D.; Kapuvári, B.; Przybylski, M.; Hudecz, F.; Mező, G. Bioconjug Chem 2009, 20, 656-665.

18. Orbán, E.; Mező, G.; Schlage, P.; Csík, G.; Kulić, Z.; Ansorge, P.; Fellinger, E.; Möller, H. M.; Manea, M. Amino Acids 2011, 41, 469-483.

19. Leurs, U.; Mezö, G.; Orbán, E.; Öhlschläger, P.; Marquardt, A.; Manea, M. Biopolymers 2012, 98, 1-10. 
20. Manea, M.; Leurs, U.; Orbán, E.; Baranyai, Z.; Öhlschläger, P.; Marquardt, A.; Schulcz, Á.; Tejeda, M.; Kapuvári, B.; Tóvári, J.; Mező, G. Bioconjug Chem 2011, 22, 1320-1329.

21. Schlage, P.; Mező, G.; Orbán, E.; Bősze, S.; Manea, M. J Control Release 2011, 156, 170-178.

22. Montagnani Marelli, M.; Manea, M.; Moretti, R. M.; Marzagallia, M.; Limonta, P. Int J Oncol 2015, 46, 243-253.

23. Leurs, U.; Lajkó, E.; Mező, G.; Orbán, E.; Öhlschläger, P.; Marquardt, A.; Kőhidai, L.; Manea, M. Eur J Med Chem 2012, 52, 173-183.

24. Galande, A. K.; Hilderbrand, S. A.; Weissleder, R.; Tung, C. H. J Med Chem 2006, 49, 4715-4720.

25. Monsó, M.; Tarradas, J.; de la Torre, B. G.; Sobrino, F.; Ganges, L.; Andreu, D. J Pept Sci 2011, 17, 24-31.

26. Schwöppe, C.; Zerbst, C.; Fröhlich, M.; Schliemann, C.; Kessler, T.; Liersch, R.; Overkamp, L.; Holtmeier, R.; Stypmann, J.; Dreiling, A.; König, S.; Höltke, C.; Lücke, M.; Müller-Tidow, C.; Mesters, R. M.; Berdel, W. E. J Med Chem 2013, 56, 2337-2347.

27. Mier, W.; Krämer, S.; Zitzmann, S.; Altmann, A.; Leotta, K.; Schierbaum, U.; Schnölzer, M.; Eisenhut, M.; Haberkorn, U. Org Biomol Chem 2013, 11, 2706-2711.

28. Mező, G.; Szabó, I.; Kertész, I.; Hegedüs, R.; Orbán, E.; Leurs, U.; Bősze, S.; Halmos, G.; Manea, M. J Pept Sci 2011, 17, 39-46.

29. Bartos, A.; Uray, K.; Hudecz, F. Biopolymers 2009, 92, 110-115.

30. Manea, M.; Tóvári, J.; Tejeda, M.; Schulcz, Á.; Kapuvári, B.; Vincze, B.; Mezö, G. Anticancer Drugs 2012, 23, 90-97.

31. Beyer-Sehlmeyer, G.; Glei, M.; Hartmann, E.; Hughes, R.; Persin, C.; Böhm, V.; Rowland, I.; Schubert, R.; Jahreis, G.; Pool-Zobel, B. L. Br J Nutr 2003, 90, 1057-1070.

32. Lecona, E.; Olmo, N.; Turnay, J.; Santiago-Gómez, A.; López de Silanes, I.; Gorospe, M.; Lizarbe, M. A. Biochem J 2008, 409, 311-320.

33. Scharlau, D.; Borowicki, A.; Habermann, N.; Hofmann, T.; Klenow, S.; Miene, C.; Munjal, U.; Stein, K.; Glei, M. Mutat Res 2009, 682, 39-53. 


\section{Figure legends}

Fig. 1. Structure representation of bioconjugates 1 and 2. Cleavage sites identified by mass spectrometry after incubation with rat liver lysosomal homogenates are marked by arrows.

Fig. 2. Stability of GnRH-III $\left[{ }^{8} \operatorname{Lys}\left(\mathrm{Dau}=\mathrm{Aoa}-\mathrm{GFLG}_{-} \mathrm{EG}_{1}\right)\right]$ (2) in human serum: (A) ESI-ion trap mass spectrum recorded after $24 \mathrm{~h}$ of incubation of the bioconjugate with $90 \%$ human serum. ESI-ion trap mass spectrum was averaged over the chromatographic window where the compounds eluted. The $\mathrm{m} / \mathrm{z}$ values corresponding to the intact bioconjugate were marked bold. (B) Human serum control and (C) Aqueous solution of GnRH-III $\left[{ }^{8}\right.$ Lys $($ Dau $=$ Aoa-GFLG-EG 1$\left.)\right]$ after $24 \mathrm{~h}$ of incubation at $37^{\circ} \mathrm{C}$.

Fig. 3. Cellular uptake of GnRH-III $\left[{ }^{8} \mathrm{Lys}(\mathrm{Dau}=\mathrm{Aoa}-\mathrm{GFLG})\right]$ and GnRH-III $\left[{ }^{8} \mathrm{Lys}(\mathrm{Dau}=\mathrm{Aoa}-\right.$ GFLG-EG 1 )] bioconjugates by MCF-7 human breast cancer cells.

Fig 4. Structure representation of bioconjugates 3-6. Cleavage sites that were identified by mass spectrometry after their incubation with rat liver lysosomal homogenates were marked by arrows.

Scheme 1. Outline of the synthesis of bioconjugate 5 . 
Table 1. Solubility in cell culture medium of oxime bond-linked daunorubicin-GnRH-III derivative bioconjugates $\mathbf{1}$ and $\mathbf{2}$

\begin{tabular}{|c|c|c|}
\hline Solubility & Compound 1 & Compound 2 \\
\hline in $\mu \mathrm{g}$ & 12.7 & 23.6 \\
\hline in $\mu \mathrm{mol}$ & 0.00575 & 0.00977 \\
\hline in \% & 42.5 & 78.8 \\
\hline
\end{tabular}

20

21

22

23

24

25

26

27

28

29

30

31

32

33

34

35

36

37

38

39

40

41

42

43

44

45

46

47

48

49

50

51

52

53

54

55

56

57

58

59

60

John Wiley \& Sons, Inc. 
Table 2. Solubility in cell culture medium of bioconjugates 3-6 containing two copies of Daunorubicin

\begin{tabular}{|c|c|c|c|c|}
\hline Solubility & Compound 3 & Compound 4 & Compound 5 & Compound 6 \\
\hline in $\mu \mathrm{g}$ & 8.7 & 1.1 & 26.7 & 7.9 \\
\hline in $\mu \mathrm{mol}$ & 0.00327 & 0.0033 & 0.00903 & 0.00213 \\
\hline in \% & 16.4 & 1.6 & 45.1 & 10.6 \\
\hline
\end{tabular}


Table 3. In vitro cytostatic effect of bioconjugates 3-6 on MCF-7 human breast cancer cells

\begin{tabular}{|c|c|c|}
\hline $\begin{array}{l}\text { Compound } \\
\text { Nr. }\end{array}$ & Compound Code & $\begin{array}{l}\text { Cytostasis } \\
\text { MCF-7 } \\
\text { IC }_{50}(\mu \mathrm{M})\end{array}$ \\
\hline 3 & GnRH-III $\left[{ }^{4} \operatorname{Lys}(n B u),{ }^{8} \operatorname{Lys}(\mathrm{Dau}=\mathrm{Aoa}-\mathrm{Lys}(\mathrm{Dau}=\mathrm{Aoa}))\right]$ & $7.7 \pm 0.4$ \\
\hline 4 & $\begin{array}{c}\text { GnRH-III }\left[{ }^{4} \operatorname{Lys}(n B u),{ }^{8} \operatorname{Lys}(\text { Dau }=\text { Aoa-GFLG-Lys }(\text { Dau=Aoa- }\right. \\
\text { GFLG }))]\end{array}$ & $1.3 \pm 0.4$ \\
\hline 5 & GnRH-III $\left[{ }^{4} \operatorname{Lys}(n B u),{ }^{8} \operatorname{Lys}\left(\mathrm{Dau}=\mathrm{Aoa}-\mathrm{EG}_{2}-\mathrm{Lys}\left(\mathrm{Dau}=\mathrm{Aoa}-\mathrm{EG}_{2}\right)\right)\right]$ & $0.9 \pm 0.4$ \\
\hline 6 & 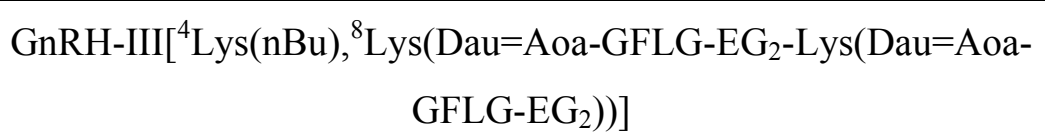 & $0.5 \pm 0.1$ \\
\hline
\end{tabular}

John Wiley \& Sons, Inc. 


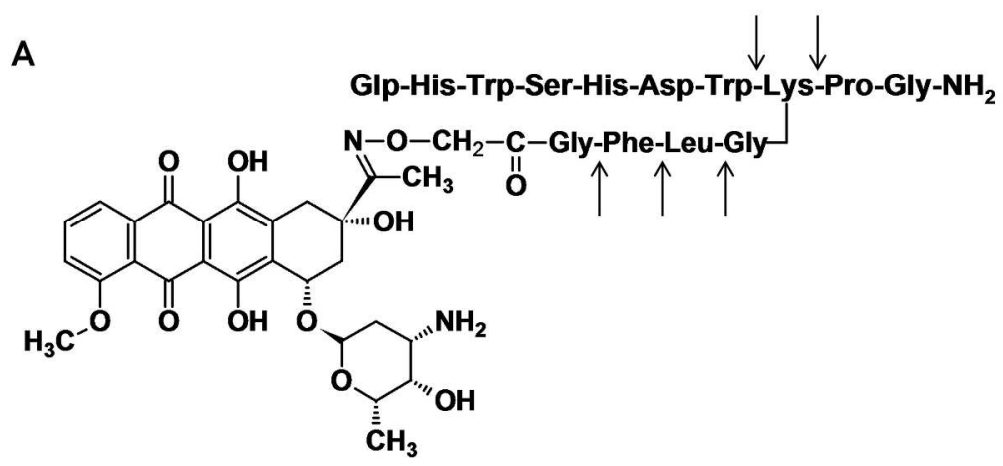

1, GnRH-III['Lys(Dau=Aoa-GFLG)] 



Stability of GnRH-III[8Lys(Dau=Aoa-GFLG-EG1)] (2) in human serum: (A) ESI-ion trap mass spectrum recorded after $24 \mathrm{~h}$ of incubation of the bioconjugate with $90 \%$ human serum. ESI-ion trap mass spectrum was averaged over the chromatographic window where the compounds eluted. The $\mathrm{m} / \mathrm{z}$ values corresponding to the intact bioconjugate were marked bold. (B) Human serum control and (C) Aqueous solution of GnRH-III[8Lys(Dau=Aoa-GFLG-EG1)] after $24 \mathrm{~h}$ of incubation at $37^{\circ} \mathrm{C}$. $254 \times 338 \mathrm{~mm}(300 \times 300 \mathrm{DPI})$ 
Stability of GnRH-III[8Lys(Dau=Aoa-GFLG-EG1)] (2) in human serum: (A) ESI-ion trap mass spectrum recorded after $24 \mathrm{~h}$ of incubation of the bioconjugate with $90 \%$ human serum. ESI-ion trap mass spectrum was averaged over the chromatographic window where the compounds eluted. The $\mathrm{m} / \mathrm{z}$ values corresponding to the intact bioconjugate were marked bold. (B) Human serum control and (C) Aqueous solution of GnRH-III[8Lys(Dau=Aoa-GFLG-EG1)] after $24 \mathrm{~h}$ of incubation at $37^{\circ} \mathrm{C}$. $254 \times 338 \mathrm{~mm}(300 \times 300 \mathrm{DPI})$ 


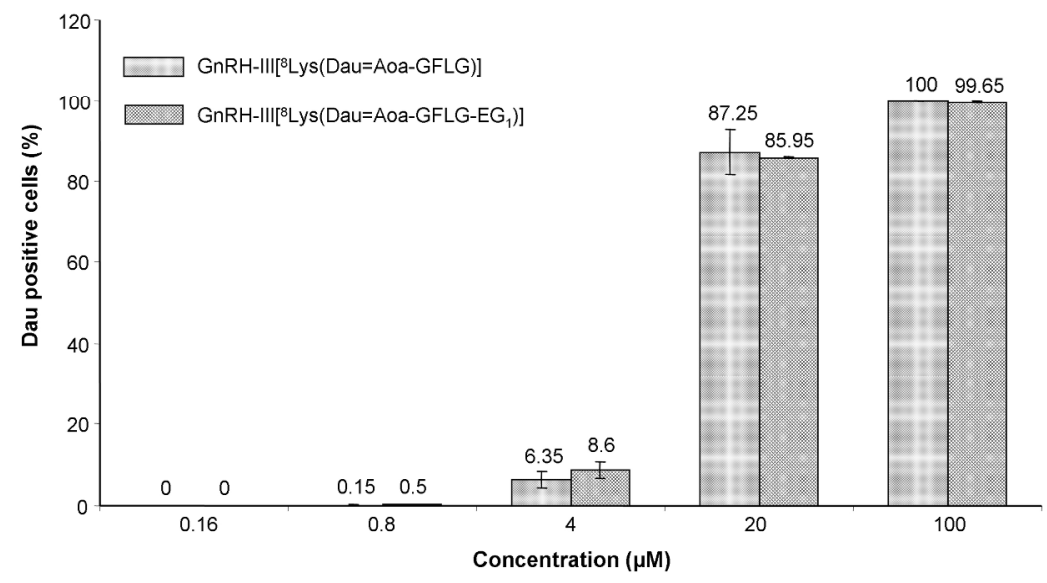

Cellular uptake of GnRH-III[8Lys(Dau=Aoa-GFLG)] and GnRH-III[8Lys(Dau=Aoa-GFLG-EG1)] bioconjugates by MCF-7 human breast cancer cells. $254 \times 190 \mathrm{~mm}(300 \times 300 \mathrm{DPI})$

John Wiley \& Sons, Inc. 
A

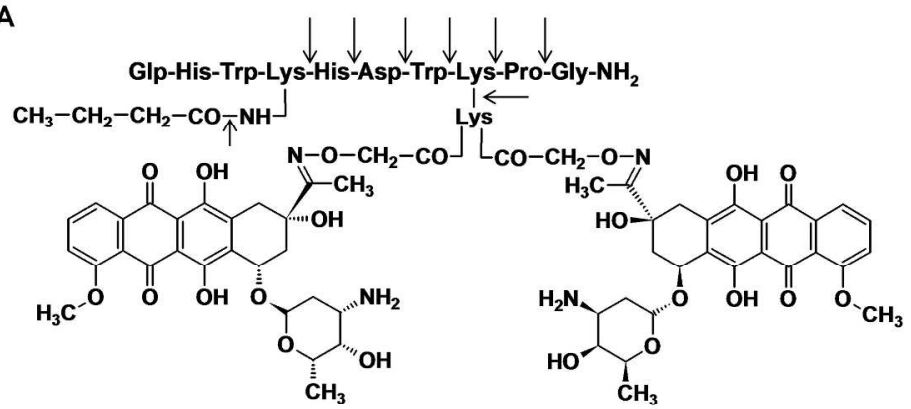

3, GnRH-III $\left\{{ }^{4} \mathrm{Lys}(\mathrm{nBu}),{ }^{8} \mathrm{Lys}[\mathrm{Dau}=\mathrm{Aoa}-\mathrm{Lys}(\mathrm{Dau}=\mathrm{Aoa})]\right\}$

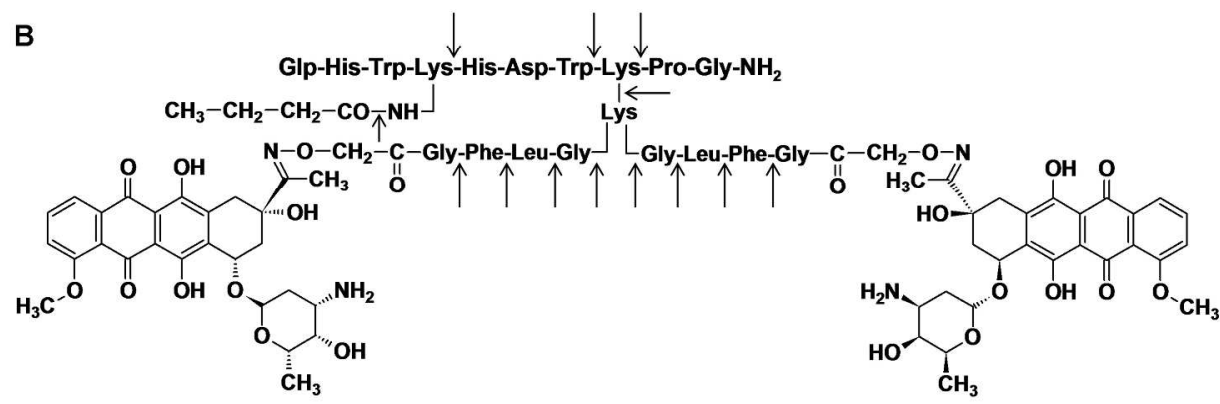

4, GnRH-III $\left\{\right.$ Lys(nBu), ${ }^{8}$ Lys(Dau=Aoa-GFLG-Lys(Dau=Aoa-GFLG) $\left.]\right\}$

Structure representation of bioconjugates 3-6. Cleavage sites that were identified by mass spectrometry after their incubation with rat liver lysosomal homogenates were marked by arrows. $254 \times 190 \mathrm{~mm}(300 \times 300$ DPI $)$ 


\section{Structure representation of bioconjugates 3-6. Cleavage sites that were identified by mass spectrometry} after their incubation with rat liver lysosomal homogenates were marked by arrows. $254 \times 190 \mathrm{~mm}(300 \times 300$ DPI $)$ 


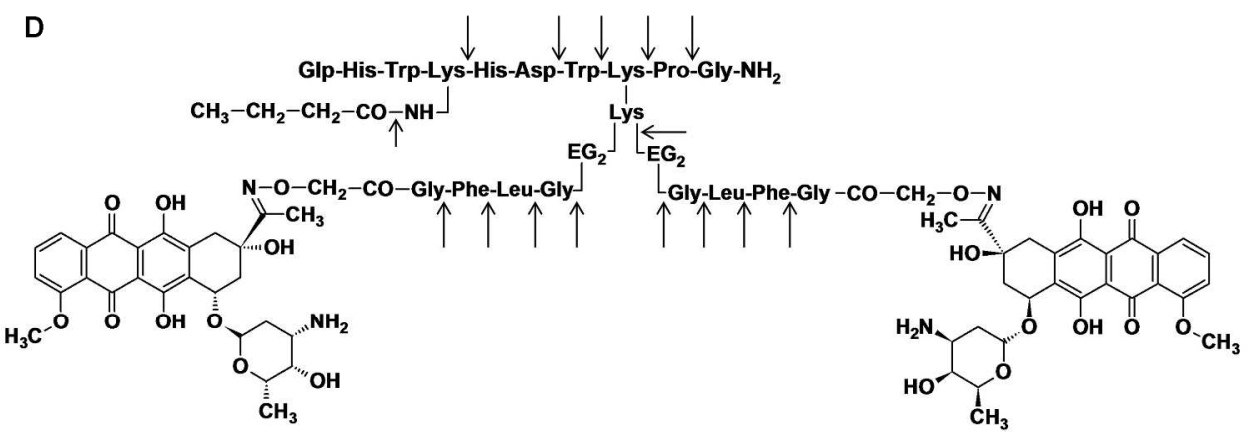

6. GnRH-III $\left\{\right.$ Lys(nBu), ${ }^{8}$ Lys( Dau=Aoa-GFLG-EG ${ }_{2}$-Lys(Dau=Aoa-GFLG-EG 2$\left.\left.)\right]\right\}$

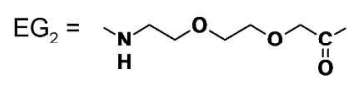

\section{Structure representation of bioconjugates 3-6. Cleavage sites that were identified by mass spectrometry} after their incubation with rat liver lysosomal homogenates were marked by arrows. $254 \times 190 \mathrm{~mm}(300 \times 300$ DPI $)$ 
Glp-His(Trt)-Trp-Lys(Dde)-His(Trt)-Asp(O'Bu)-Trp-Lys(Mtt)-Pro-Gly-

1. Dde cleavage: $2 \%$ hydrazine/DMF

2. Butyric anhydride - DIEA (3-3 equiv)/DMF

Glp-His(Trt)-Trp-Lys(nBu)-His(Trt)-Asp(OtBu)-Trp-Lys(Mtt)-Pro-Gly-

Outline of the synthesis of bioconjugate 5 .

$254 \times 190 \mathrm{~mm}(300 \times 300 \mathrm{DPI})$ 